
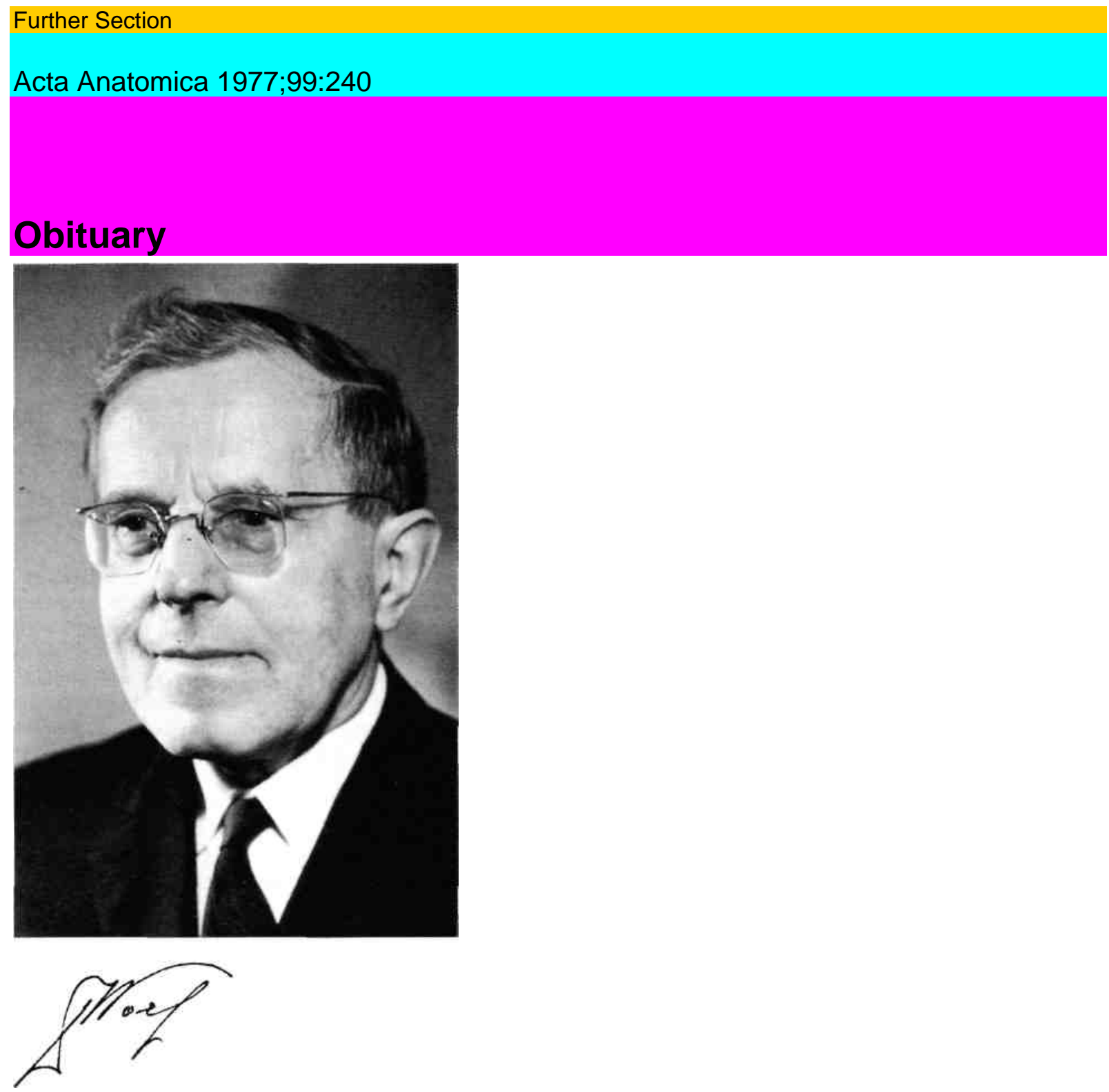

\title{
Jan Wolf
}

Professor Jan Wolf, Doctor of Medicine (medi-cinae universae doctor), Doctor of Sciences, member of the Czechoslovak Academy of Sciences, died January 10th, 1977. Jan Wolf (born May 13th, 1894) graduated as 'medicinae universae doctor' at the Charles University in Prague (1919). After the graduation, Jan Wolf was a lecturer at the Department of Histology and Embryology of the Charles University Medical Faculty, Prague, where he received the academic positions of an Assistant Professor (1924), Associate Professor (1927) and Professor (1938). Since 1947, Professor Wolf was acting as the Chairman of the Department of Histology at the same medical school. In 1953, Jon Wolf was nominated as the Founding Member of the Czechoslovak Academy of Sciences and the External and - after the retirement at the Charles University - Internal Director of the Laboratory of Electron Microscopy at the same institution.

Professor Wolf was mainly interested in the functional morphology of the pancreatic endocrine tissues, cartilage, joints, placenta, dental tissues, stratified epithelium, lung and eye tissues. He is also the founder of the plastic histology numerous years before the introduction of the scanning microscopy in the biological and medical sciences.

Jon Wolf was one of the senior members of the 'Association des Anatomistes', chairman of the Czechoslovak Committee for Electron Microscopy, Founding and Honorary Member of the Czechoslovak Anatomical Society, editor of the Folia morphologica, member of the 
editorial boards of the Comptes rendus de ГAssociation des Anatomistes, of the Zeitschrift für mikroskopisch-anatomische Forschung, and the Acta anatomica, since the foundation of our periodical until his retirement.

For his scientific and pedagogic efforts Professor Wolf was honored by receiving numerous awards such as the State Order of Work, the Purkinje Medal of the Czechoslovak Medical Society, the Gold Plate of the Czechoslovak Academy of Sciences for the Merit in Science and Humanity, the Gold Mendel's Plate of the Czechoslovak Academy of Sciences for the Contribution in Biological Sciences, etc.

The death of Professor J $\alpha$ Wolf represents a great loss for the Czechoslovak medical and biological sciences. 